\title{
TFE3 wt Allele
}

National Cancer Institute

\section{Source}

National Cancer Institute. TFE3 wt Allele. NCI Thesaurus. Code C53110.

Human TFE3 wild-type allele is located in the vicinity of Xp11.22 and is approximately 17 $\mathrm{kb}$ in length. This allele, which encodes transcription factor E3 protein, plays a role in the regulation of immunoglobulin expression. The gene is involved in chromosomal aberrations that are associated with papillary renal cell carcinoma and alveolar soft part sarcoma. 